\title{
The Political Economy of Turkey's Integration into the MENA Economy
}

Imad El-Anis ${ }^{1}$

\section{Introduction}

In the early post-Cold War era, space opened-up for renewed Turkish interest in the Middle East and North Africa (MENA), and Central Asia - regions in which the Ottoman Empire, as the predecessor to the modern Turkish Republic, had played a pivotal role. Through the 1990s and early 2000s Turkey's political, economic and socio-cultural links with the MENA, in particular, rapidly expanded. Whereas through the 1900s Ankara had looked westwards to Europe and did not pay significant attention to its neighbours to the south and east (outside of security interests), Turkey has 'rediscovered' the MENA and now plays a very significant role in the region's political and economic affairs. A body of literature has emerged that explores the emergence of these expanding ties and the policy interests driving them (see, for example: Öniş 2010; Kardaş 2010; Kirisci and Kaptanoglu 2011; Hürsoy 2013;). It is timely to deepen our understanding of the ways in which Turkey has not only reengaged with the MENA but has more fully integrated with it. Turkey now plays an important role in the region's political and economic system in a number of ways. This chapter explores this new reality by analysing the political economy of Turkey's relations with MENA partners.

According to Ziya Öniş and Mustafa Kutlay $(2013,1412)$ '[t]he current proactivism in Turkish foreign policy [...] increasingly relies on two pillars: economic interdependence, and explicit prodemocracy rhetoric.' It is the first of these two pillars that is the focus of this chapter. Levent Aydin and Mustafa Acar $(2013,42)$ highlights that there is '[n]o doubt that the greater Middle East [...] capture[s] more attention now in the new Turkish foreign policy as opposed to the past.' And that '[c]hanging patterns or direction in Turkey's foreign trade could be taken as one of the indicators' of this shift in Turkey's foreign economic policy. Understanding these changing patterns in its economic interactions with the MENA will allow us to better understand the extent to which Turkey is integrating with its neighbours to the south and east, and whether this integration is symmetrical or asymmetrical - which will largely determine whether Turkey is an emerging regional hegemon, or simply a key part of a broader regional market. This chapter explores these issues by analysing several aspects of Turkey's economic interactions with states in the broader MENA in terms of commercial institutions, trade volumes and balance, foreign direct investment (FDI), and the role of Turkish corporations.

This chapter employs a mixed-method approach that favours quantitative analysis of macroeconomic linkages between Turkey and the MENA, and qualitative analysis of the interests and discourse informing institutional interactions. We will first consider the ways in which the political economy of Turkey's integration into the MENA regional economy has been framed. Then we will explore Turkey-MENA trade and FDI patterns and structures. The importance of Turkish corporations will be highlighted before conclusions are drawn about the importance and longevity of Turkey's integration with the region.

\section{Conceptualising Turkey-MENA Economic Integration}

There is some validity to the claim that in the historical context, the abolishment of the Caliphate and Ottoman dynasty cut ties and "breached the "social contract" between Kurds, Arabs and Turks' (Ehteshami and Elik 2011, 644). The leading view now is that "[a] major structural transformation in

\footnotetext{
${ }^{1} \mathrm{Dr}$ Imad El-Anis is Senior Lecturer in International Relations at Nottingham Trent University, UK. imad.el-anis@ntu.ac.uk
} 
Turkish central-periphery relations occurred when the Justice and Development Party [...] won parliamentary elections in November 2002. The nature of Turkey's policy toward the Middle East changed under the banner of new activism in Turkish foreign policy' (Ibid., 645-646). However, it can also be argued that ' $[t]$ his characterization is an injustice to the continuation in Turkey's relations with the region' (Ibid.). Nevertheless, as will be discussed below, Turkey's economic relations with the MENA (in particular, trade and FDI, and the roles that Turkish corporations play) has deepened since the early 2000s and in many ways has repositioned Turkey in the broader MENA market. Some scholars (see: Pollack 2005; Cagaptay 2009) state that Turkey's supposed 'Eastern Turn' has been driven by the AKP's Islamist agenda, while others (see: Kirisci 2009, 2011; Logan 2009) claim that changes in Turkey's domestic and foreign economic relations have transformed Turkey into a 'trading state' and there is nothing unique about Turkey's economic integration with the MENA. Thus, Turkey's 'foreign policy is guided to a greater extent by economic considerations such as trade, export markets, [FDI], and energy security' (Ekmekci and Yildirim 2013, 53). Kirisci (2011, 33-34) claims that 'economic considerations such as the need to trade, expand exports, and attract and export [FDI]' have replaced narrow security considerations as the main drivers behind Turkey's foreign policy-making. While Ekmeci and Yildirim $(2013,58)$ find that Turkey's economics-first approach has in some ways necessitated the 'maintenance of good neighbourly relations with countries in the [MENA]'. In other words, Turkey's economic interests now heavily influence its broader foreign interests rather than the other way around as in the past. Furthermore, Turkey has largely followed a neo-functionalist framework in order to maximise gains from both the economic opportunities that the MENA market represents, and the interdependence that accompanies greater levels of trade and FDI. This has allowed Turkey to institutionalise its relations with MENA states by 'downgrading military power in favor of economic interactions' (Kutlay 2011, 71).

Ageliki and loannis $(2016,285)$ find that 'Turkey's trade integration in the world system is [...] balanced while, at the same time, Turkey seems to develop intensive trade relations with specific subsystems in [the] Eurasian region based on geographical (in a broader geopolitical sense), cultural and historical proximities.' This is in contrast to the Interwar and Cold War eras when Turkey's political and economic strategies toward the MENA were perceived by its neighbours, in particular Arab states, as founded on the need to balance extra-regional and regional actors and not as a sign that Turkey sought to become the regional hegemon (Ehteshami and Elik 2011, 646). This perception of Turkey as a balancing rather than aggressive actor in the region has merit when considering the changes taking place within Turkey's domestic political economy. In the early 2000s a 'power shift in domestic finance capital underpinned an active foreign policy engagement' (Kutlay 2011, 75). The increased power and influence of the Anatolian Tigers in this period helped to change the economic structures informing power relations within Turkey which 'inevitably spilled-over into foreign policy' (Ibid.). The rise of the Anatolian Tigers allowed the emergent Anatolian bourgeoisie to have a greater say in where Turkey looked for both inspiration and for opportunities to exploit. Thanks to 'geographical proximity and cultural factors' Turkish policy-makers were encouraged to reformulate their policies towards both the MENA and Central Asia (Ibid., 76). In effect, Turkey began to look east and south, finding economic, political and socio-cultural opportunities to expand its role in the global political economy.

We can identify three sets of structures that have informed the manner in which this deepening of Turkey's role in the MENA (what we can term its reintegration into the region - at least in terms of its economic relations) has taken place. Firstly, we can consider material interests. 'The material interests established between Turkish firms and neighbouring countries' are a clear demonstration of the integrative relationships that underpin Turkey's foreign policy activism since the AKP assumed power in 2002. Mustafa Kutlay refers to the economic and personal interactions between Turkish businesspersons and their counterparts from other MENA states as one of the 
practical hands of Turkey's diplomacy (Ibid., 77-78). The second key structure is the multiple dialogue channels that originate in the business realm, but which have spilled-over (in the rather classical functionalist sense) into other areas of Turkey's state and market interactions with MENA actors. 'The increasing intensity of commercial relationships between Anatolian businessmen and [MENA] markets has created spill-over effects and facilitated the establishing of new dialogue and cooperation mechanisms' (Ibid., 80). Furthermore, the deepening of economic links between Turkey and its MENA neighbours has a significant impact on the broader relationship between Turkey and the region, as 'relationships are not restricted to bureaucratic state-state relations anymore. The interaction between non-state actors at different levels and on different issue areas has multiplied the ways in which parties gather information about each other' (Ibid., 81). The third way in which Turkey's reintegration into the MENA market has been shaped are the perceptions of Turkey's roles and interests by other MENA actors. Kutlay concludes that 'the spill-over effects of commercial interests and the institutionalization of multiple dialogue channels in new relationships [have] gradually change[d] perceptions' (Ibid.). In particular, Arab perceptions of Turkey have changed since the early 2000 s, with surveys finding that a majority (approximately 75\%) of the Arab population now view Turkey either very positively or positively. We should not underestimate the role of Turkey's economic interactions with the region here. Increasing economic interdependence has encouraged more intense 'interaction and human mobility that [has] changed the historically and ideologically loaded (mis)perceptions' (Ibid., 81-82) of communities in Turkey and the Arab world.

Economic interactions between Turkey and the MENA should also be considered in the broader context of Turkey's position on the world stage. Anoushiravan Ehteshami and Suleyman Elik $(2011,646)$ argue that Turkey has aspirations in the global political economy that extend well beyond its roles in the MENA and Central Asia. 'Turkey sees the Middle East as a key strategic region in the global power struggle, in addition to its concerns over access to the region's gas and oil resources.' Specifically, they suggest that Turkey's reintegration with the MENA as a whole, and with Iran and the larger Arab states in particular, has become 'a function of Ankara's application of its soft power, which includes broad economic engagement and deepening ties in the energy sector' (Ibid., 657-658). Although Turkey remains economically connected to Europe, North America, and South and East Asia, by integrating with the MENA, it has been able to increase its relative economic power and political importance on the world stage (Kirisci et al. 2010) and offset some of its reliance on Western markets - which come with political considerations that hinder Turkey's ability to pursue its broader foreign policy goals (Sorhun 2013, 22). This reorientation of Turkey's overarching foreign policy strategy and its involvement in the MENA, in particular, date back to at least the 2002 electoral success of the AKP (Öniş and Yilmaz 2009). Englin Sorhun $(2013,22)$ highlights, however, that the MENA does not represent a panacea for Turkey's weaknesses. 'The Arab Spring has been jeopardizing Turkish export market[s] and this has a possibility of breaking down the recent development in trade flows. Moreover, political instability, the risk of war, worsened economic situation, [and] slowing reform process resulting from awakening movements seem to be the signs that the impacts of the Arab Spring on trade flows can last longer.'

The limitations of relying on economic integration with the MENA to help Turkey develop greater leverage in its broader international relations also informs the move away from its longstanding strategic policy of 'zero problems with neighbours' (ZPN) that was dominant in the early 2000s. Turkey attempted to 'develop relations with [the] Arab world as a trade partner at the beginning of the 1990s [but] it did not last long. Trade volume with Arab countries remained below [their] potential level until the implementation of the [ZPN] policy' in 2002 (Ibid., 23). The most obvious macro-economic impact of the ZPN was that Turkey 'diversified its export markets especially with the members of the Organisation for Islamic Cooperation (OIC) [this] market diversification 
alleviated the dependence of Turkey on [the] European export market' (Ibid., 25) and made it less vulnerable to the global economic recession that followed the 2008-2009 financial crisis. Yet, while economic interactions between Turkey and the MENA have dramatically increased (as demonstrated below) since 2002, Turkey has been unable to insulate itself from the upheavals of the Arab Spring in 2010-2011 (note that Turkey was very active in the region prior to 2010 (Kardas 2010)) and the postArab Spring instability experienced by many states in the region. It has been one of the most actively engaged external actors in Syria's civil war, for example, and this has undermined its relations with leading international powers as well as the Syrian regime of Bashar al-Assad. Some now argue that the ZPN policy was drastically undermined, or even purposefully changed post-2011 into a 'zero friends policy' (Subasat 2017, 1). Regardless of the post-2011 changes in Turkey's security relations with the MENA, previous work to institutionalise its political and economic relations with Iran and the Arab states has embedded and formed a framework that looks may facilitate greater economic interdependence over the coming years. We now turn to an overview of the main institutional mechanisms and Turkey's trade relations with the region.

\section{Turkey's Bilateral Trade with MENA States}

The post-2002 expansion of Turkey's foreign trade and its integration with the regional economy in the MENA are part of a longer-term and somewhat deep-rooted restructuring of the Turkish economy along neo-liberal lines that dates back to the 1980s (see: Donmez and Zemandl 2019; Öniş and Senses 2009). Europe remains the most important single regional market for Turkey (both in terms of imports and exports) and the Turkey-EU Customs Union Agreement (in force since 1995) reflects this fact. Turkey has also pursued (with some vigour) greater institutionalisation of its trade relations with the global economy (Turkey was a member of GATT since 1951 and a subsequent founding member of the World Trade Organisation (WTO) in 1995) and the MENA. Turkey is a member of a number of commercial institutions, including: a free trade agreement (FTA) with the Economic Cooperation Organization (Afghanistan, Azerbaijan, Iran, Kazakhstan, Kyrgyzstan, Pakistan, Tajikistan, Turkmenistan and Uzbekistan); the European Free Trade Area (Iceland, Liechtenstein, Norway and Switzerland); and bilateral FTAs with: Albania, Bosnia and Herzegovina, Chile, Croatia, Egypt, Georgia, Israel, Jordan (at the time of writing this FTA was being re-negotiated), Macedonia, Malaysia, Mauritius, Moldova, Montenegro, Morocco, Palestine, Serbia, Singapore, South Korea, Syria (suspended at the time of writing) and Tunisia. While the effectiveness of commercial institutions on creating trade and promoting political cooperation (read: peace and stability in international relations) is still debated (see: Oneal and Russett 1999; Polachek et al. 1999; Aydin 2010; Barbieri 1996; El-Anis 2018), it is clear that the Turkish government has sought to institutionalise its economic integration with the global economy. Ankara wants either to facilitate trade and deepen economic integration or to promote channels for political dialogue (or both) and the MENA and Central Asia feature quite prominently here with 16 of Turkey's 35 FTA partners being in these regions.

Turkey's over-arching foreign economic policies appear to have significantly influenced both the country's position in the global economy and its economic integration with states both near and far. Turkey has now become deeply integrated into the world economy as its 14th largest national market by purchasing power (\$2.173 trillion (Wold Bank, 2018)) and an outward-oriented trading state - albeit one with significant imports too. A survey of Turkey's trading partners demonstrates the deepening level of global integration that the Turkish economy has achieved in the past two decades or so, and the increasing importance of the MENA market for Turkey. Its leading trade partners are located across different regions (see Table 1). Perhaps unsurprisingly, given their historical and contemporary political and socio-cultural connections, Turkey's leading trade partner remains 
Germany with bilateral trade totalling $\$ 35.474$ billion in 2016 . Turkey exports more goods and services to Germany than anywhere else ( $\$ 13.999$ billion in 2016 , equivalent to $9.82 \%$ of all Turkish exports), but it also imports more from Germany (\$21.475 billion, $10.8 \%$ of all imports) than anywhere else except China. This means that the 2016 balance of trade favoured Germany by $\$ 7.476$ billion (this is Turkey's third largest trade deficit with any individual trade partner). As is the case for many states, China is also a key trading partner for Turkey and bilateral trade in 2016 totalled $\$ 27.77$ billion, with imports from China amounting to $\$ 25.441$ billion, equivalent to $12.8 \%$ of Turkey's total imports that year, which is good enough to be Turkey's largest source of imports. At the same time, however, Turkish exports to China are quite limited, totalling only $\$ 2.328$ billion in 2016, equivalent to $1.63 \%$ of Turkey's exports, and leading to Turkey's largest trade deficit with any single state $\mathbf{\$} 23.113$ billion in 2016). The rest of Turkey's top 20 trading partners demonstrate Turkey's advanced trading links with Europe, ${ }^{2}$ North America, ${ }^{3}$ Asia, ${ }^{4}$ and the MENA. ${ }^{5}$

Interestingly out of Turkey's top trading partners, only four are from the MENA. However, Iran, the UAE, Iraq and Saudi Arabia together did represent over $\$ 32$ billion in total trade for Turkey in 2016, and importantly Turkey has trade surpluses with each of them. Turkey's total trade with Iran is larger than with any other MENA state at $\$ 9.665$ billion in 2016 , and while it had a trade surplus of only \$266.4 million, Iran represents Turkey's largest imports market in the region (\$4.7 billion in imports in 2016 , equivalent to $2.37 \%$ of total imports that year). Turkey exports more to Iraq (\$7.637 billion in 2016, equivalent to $5.36 \%$ of total exports) than to any other MENA state, yet it only imported $\$ 836.3$ million of goods and services in that year ( $0.4 \%$ of imports), leading to a trade surplus of $\$ 6.8$ billion, its largest with a MENA state in 2016. Turkish-Emirati bilateral trade is the second largest for Turkey in the region at $\$ 9.1$ billion in 2016 and with $\$ 5.41$ billion accounted for by Turkish exports $(3.79 \%$ of all exports) and $\$ 3.7$ billion in imports (1.86\% of all imports) leading to a Turkish trade surplus of $\$ 1.7$ billion that year. Turkish-Saudi trade expresses a similar structure but albeit of lower monetary values. Turkey exported \$2.68 billion in goods and services to Saudi Arabia in 2016 (2.23\% of total exports) and imported a further $\$ 1.835$ billion ( $0.92 \%$ of total imports) leading to a trade surplus of $\$ 1.337$ billion.

Table 1. Turkey's Trade with Leading Partners, 2016 (US\$ billions)

\begin{tabular}{|l|r|r|r|r|r|r|}
\hline \multicolumn{1}{|c|}{ State } & Exports & \multicolumn{1}{c|}{$\begin{array}{c}\text { Exports } \\
\text { (\% of } \\
\text { Total) }\end{array}$} & Imports & \multicolumn{1}{c|}{$\begin{array}{c}\text { Imports } \\
\text { (\% of } \\
\text { Total) }\end{array}$} & \multicolumn{1}{c|}{$\begin{array}{c}\text { Trade } \\
\text { Balance }\end{array}$} & \multicolumn{1}{c|}{$\begin{array}{c}\text { Total Trade } \\
\text { Volume }\end{array}$} \\
\hline Germany & 13.999 & 9.82 & 21.475 & 10.8 & -7.476 & 35.474 \\
\hline China & 2.328 & 1.63 & 25.441 & 12.8 & -23.113 & 27.77 \\
\hline Italy & 7.581 & 5.32 & 10.218 & 5.14 & -2.638 & 17.799 \\
\hline $\begin{array}{l}\text { United } \\
\text { States }\end{array}$ & 6.624 & 4.65 & 10.868 & 5.47 & -4.244 & 17.492 \\
\hline $\begin{array}{l}\text { United } \\
\text { Kingdom }\end{array}$ & 11.686 & 8.2 & 5.320 & 2.68 & 6.366 & 17.006 \\
\hline
\end{tabular}

\footnotetext{
${ }^{2}$ Italy, $3^{\text {rd }}$; the UK, $5^{\text {th }}$; Russia, $6^{\text {th }}$; France, $7^{\text {th }} ;$ Spain, $8^{\text {th }}$; the Netherlands, $13^{\text {th }}$; Poland, $15^{\text {th }} ;$ Belgium, $16^{\text {th }}$; Switzerland, $17^{\text {th }}$; Romania, $19^{\text {th }}$ and Bulgaria, $20^{\text {th }}$.

${ }^{3}$ The USA, $4^{\text {th }}$.

${ }^{4}$ India, $14^{\text {th }}$.

${ }^{5}$ Iran, $9^{\text {th }}$; the UAE, $10^{\text {th }}$; Iraq, $11^{\text {th }}$; Saudi Arabia, $18^{\text {th }}$.
} 


\begin{tabular}{|l|r|r|r|r|r|r|}
\hline Russia & 1.733 & 1.22 & 15.162 & 7.63 & -13.429 & 16.895 \\
\hline France & 6.026 & 4.23 & 7.365 & 3.71 & -1.339 & 13.391 \\
\hline Spain & 4.989 & 3.5 & 5.679 & 2.86 & -0.690 & 10.668 \\
\hline Iran & 4.966 & 3.48 & 4.7 & 2.37 & 0.267 & 9.666 \\
\hline UAE & 5.407 & 3.79 & 3.701 & 1.86 & 1.706 & 9.108 \\
\hline Iraq & 7.637 & 5.36 & 0.836 & 0.421 & 6.8 & 8.473 \\
\hline South Korea & 0.519 & 0.364 & 6.384 & 3.21 & -5.866 & 6.903 \\
\hline Netherlands & 3.589 & 2.52 & 3 & 1.51 & 0.589 & 6.59 \\
\hline India & 0.652 & 0.457 & 5.757 & 2.9 & -5.106 & 6.409 \\
\hline Poland & 2.651 & 1.86 & 3.244 & 1.63 & -0.594 & 5.895 \\
\hline Belgium & 2.548 & 1.79 & 3.2 & 1.61 & -0.653 & 5.749 \\
\hline Switzerland & 2.681 & 1.88 & 2.506 & 1.26 & 0.175 & 5.187 \\
\hline Saudi Arabia & 3.172 & 2.23 & 1.835 & 0.924 & 1.337 & 5.007 \\
\hline Romania & 2.671 & 1.87 & 2.196 & 1.11 & 0.476 & 4.867 \\
\hline Bulgaria & 2.384 & 1.67 & 2.143 & 1.08 & 0.241 & 4.526 \\
\hline
\end{tabular}

Source: World Bank, 2018.

Turkey's MENA trade structure is relatively unique in terms of the trade surpluses it generates. Out of its top 20 trading partners, Turkey has a trade deficit with 11 (all but one of which are more advanced economies in Europe, Asia and North America). The MENA allows Turkey to offset some of these deficits. In fact, in 2016 Turkey did not have a single trade deficit with any state in the MENA. While some trade surpluses were not large in comparison to some of Turkey's other trading partners in Europe, North America and Asia, Turkey's combined trade surplus with MENA states meant that a balance of $\$ 20.5$ billion flowed into Turkey from the rest of the MENA (see Table 2). This is a significant annual surplus and is all the more important given that Turkey-MENA exports accounted for almost $26 \%$ of Turkey's total exports in 2016. At the same time, though, one can question the depth of Turkish-MENA economic integration because of this trade imbalance and the limited amount of Turkish imports from the region which accounted for only 8.3\% of total Turkish imports in 2016 (or perhaps it is more a case of Turkish consumers lacking interest in MENA products and services). However, a consideration of the changes witnessed in Turkey-MENA trade over the past two decades or so does offer some relevant insights into how important this trade is becoming for Turkey.

Table 2. Turkey's Trade with MENA Partners, 2016 (US\$ billions)

\begin{tabular}{|l|r|r|r|r|r|r|}
\hline \multicolumn{1}{|c|}{ State } & Exports & \multicolumn{1}{c|}{$\begin{array}{c}\text { Exports (\% } \\
\text { of Total) }\end{array}$} & Imports & \multicolumn{1}{c|}{$\begin{array}{c}\text { Imports (\% } \\
\text { of Total) }\end{array}$} & \multicolumn{1}{c|}{$\begin{array}{c}\text { Trade } \\
\text { Balance }\end{array}$} & \multicolumn{1}{l|}{$\begin{array}{l}\text { Total Trade } \\
\text { Volume }\end{array}$} \\
\hline Iran & 4.966 & 3.48 & 4.67 & 2.37 & 0.266 & 9.666 \\
\hline UAE & 5.407 & 3.79 & 3.701 & 1.86 & 1.706 & 9.108 \\
\hline Iraq & 7.637 & 5.36 & 0.836 & 0.421 & 6.8 & 8.473 \\
\hline $\begin{array}{l}\text { Saudi } \\
\text { Arabia }\end{array}$ & 3.172 & 2.23 & 1.835 & 0.924 & 1.337 & 5.007 \\
\hline Israel & 2.956 & 2.07 & 1.386 & 0.698 & 1.57 & 4.341 \\
\hline Egypt & 2.733 & 1.92 & 1.443 & 0.727 & 1.29 & 4.176 \\
\hline Morocco & 1.469 & 1.03 & 0.918 & 0.462 & 0.551 & 2.387 \\
\hline Algeria & 1.736 & 1.22 & 0.461 & 0.234 & 1.273 & 2.2 \\
\hline
\end{tabular}




\begin{tabular}{|l|r|r|r|r|r|r|}
\hline Syria & 1.322 & 0.928 & 0.65 & 0.0329 & 1.257 & 1.387 \\
\hline Tunisia & 0.911 & 0.639 & 0.214 & 0.108 & 0.696 & 1.125 \\
\hline Libya & 0.906 & 0.636 & 0.161 & 0.0811 & 0.745 & 1.067 \\
\hline Lebanon & 0.735 & 0.515 & 0.82 & 0.0412 & 0.653 & 0.817 \\
\hline Jordan & 0.711 & 0.499 & 0.102 & 0.0515 & 0.609 & 0.813 \\
\hline Qatar & 0.439 & 0.308 & 0.271 & 0.136 & 0.168 & 0.71 \\
\hline Kuwait & 0.431 & 0.303 & 0.11 & 0.0557 & 0.321 & 0.542 \\
\hline Yemen & 0.536 & 0.376 & 0 & 0 & 0.536 & 0.536 \\
\hline Sudan & 0.461 & 0.323 & 0.05 & 0.025 & 0.411 & 0.51 \\
\hline Bahrain & 0.193 & 0.136 & 0.128 & 0.0643 & 0.066 & 0.321 \\
\hline Oman & 0.244 & 0.171 & 0.049 & 0.0247 & 0.195 & 0.293 \\
\hline Mauritania & 0.073 & 0.0514 & 0.015 & 0.00762 & 0.058 & 0.088 \\
\hline
\end{tabular}

Source: World Bank, 2018.

Through the mid- to late-1990s Turkey's total trade with the MENA remained limited, generally around $\$ 8$ billion a year and never exceeding $\$ 10$ billion (see Table 2). This trade also remained largely constant with little sign of increasing interaction even though the MENA market did expand quite significantly during this decade. There was a clear economic transformation, however, after 2002 when there was a dramatic and rapid increase in Tukey's bilateral trade with MENA states. We cannot be entirely certain about whether or not this increase resulted from the AKP coming into power, and its subsequent policies aimed at institutionalised economic integration with the region as discussed above, but the coincidence is significant. It is possible that the AKP decision-makers at the time had identified emerging patterns of economic interaction with MENA states and sort to facilitate these. Either way, Turkey-MENA trade through the 2000s grew exponentially, reaching almost $\$ 45$ billion in 2008 until declining to $\$ 33.6$ billion in 2009 , which was largely caused by the global financial crisis and recession of 2008-2009, which negatively affected Turkey's overall foreign trade and not just that with the MENA. By 2010, Turkey's trade with the region once again began to grow rapidly reaching \$71.8 billion in 2012 until a slowdown and decline from 2013 (\$66.9 billion) to 2016 (\$53.7 billion). This latter period coincides with significant regional turmoil that has negatively affected the region's market as a whole. This turmoil includes the following: the worsening of the Syrian civil war and its internationalisation, with Russian, US, Saudi Arabian, Iranian and Turkish involvement, in particular, deepening; the rise of ISIS in Syria and Iraq and the subsequent conflict to defeat it; increased tension between Iran and its Arab neighbours; the Saudi-led coalition's involvement in Yemen's civil war; and deteriorating relations between Qatar and its GCC and broader Arab neighbours. Regardless of these periods of decline in 2009 and 2013-2015, Turkey-MENA trade has grown by approximately $900 \%$ since 2002 , a very dramatic increase given the lack of growth in the pre-2002 era.

Figure 1. Turkey's Trade Balance with MENA Partners, 2016 (US\$ billions) 


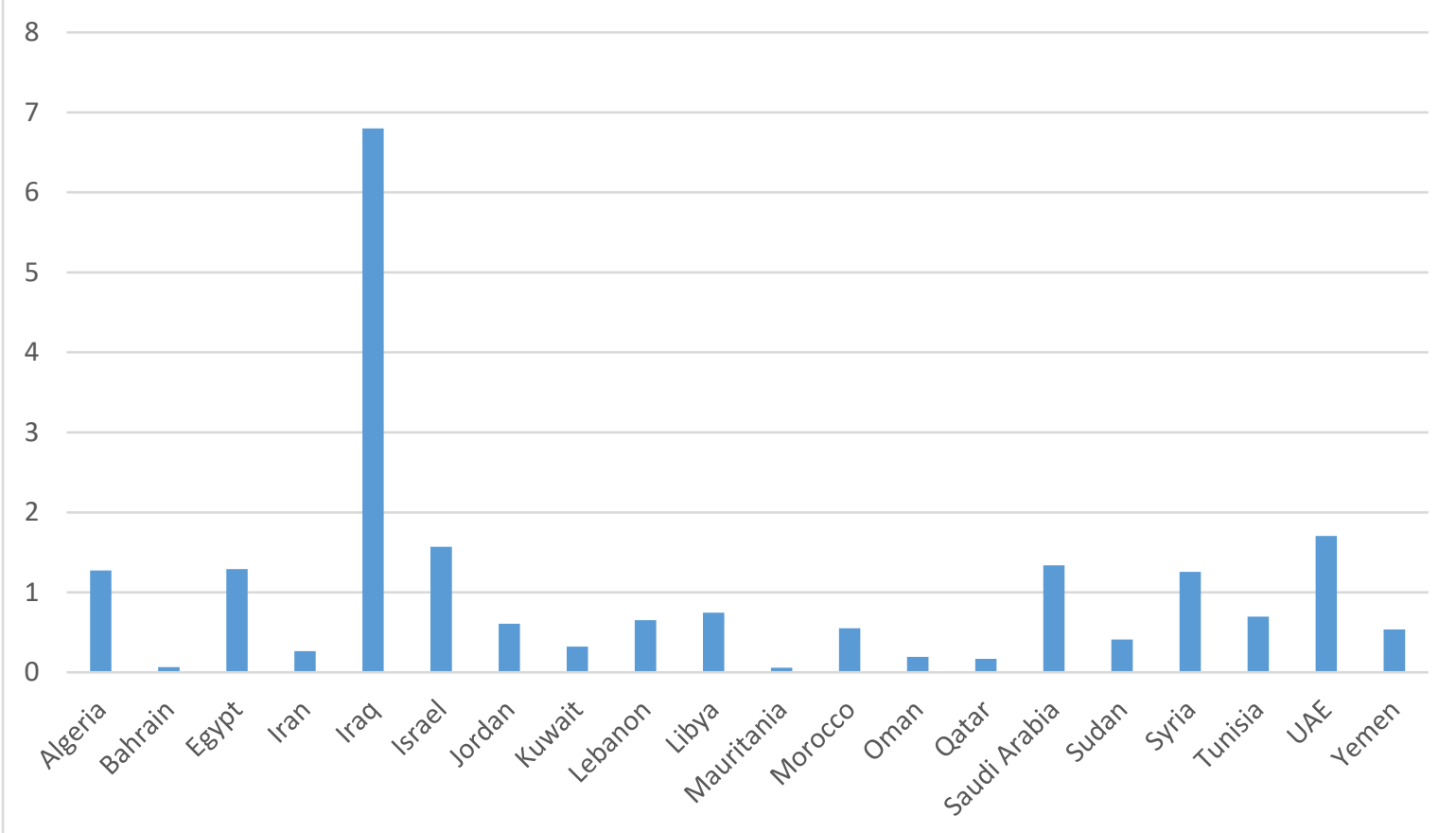

Source: World Bank, 2018.

Interestingly, Turkey's economic relationships with MENA states are not heavily affected by geographical proximity except for with Iran and Iraq, Turkey's first and third largest trading partners. Syria ranks ninth out of the 20 MENA states considered here in terms of total trade with Turkey, although, of course, trade between these two states has been negatively impacted by Syria's civil war. Beyond Turkey's immediate neighbours the mix of key trading partners in the region becomes varied with the UAE $\left(2^{\text {nd }}\right)$, Saudi Arabia $\left(4^{\text {th }}\right)$, Israel $\left(5^{\text {th }}\right)$, and Egypt $\left(6^{\text {th }}\right)$ being somewhat close to Turkey. However, Turkey's other main regional trade partners are not nearby: Morocco $\left(7^{\text {th }}\right)$, Algeria $\left(8^{\text {th }}\right)$, Tunisia $\left(10^{\text {th }}\right)$ and Libya $\left(11^{\text {th }}\right)$ account for the majority of Turkey's remaining trade with the MENA. Proximity is less important in determining Turkey's MENA trade than other variables including, the overall size of partners' markets, trading partners' levels of economic development, and the success of private sector actors (especially Turkish corporations operating in the region) in foreign markets. Turkey exports 'finished goods to and imports raw materials and energy commodities from [Arab countries]. Raw materials and energy commodities are the only goods [...] leading to production complementarity' (Sorhun 2013, 26). Turkey trades more with the larger economies of the region and those that are more advanced. 
Table 3. Turkey's Total Trade with the MENA, 1996-2017 (US\$ billions)

\begin{tabular}{|c|c|c|c|c|c|c|c|c|c|c|c|c|c|c|c|c|c|c|c|c|c|}
\hline & $\begin{array}{l}\text { Alge } \\
\text { ria }\end{array}$ & $\begin{array}{l}\text { Bahr } \\
\text { ain }\end{array}$ & $\begin{array}{l}\text { Egy } \\
\text { pt }\end{array}$ & Iran & Iraq & $\begin{array}{l}\text { Isra } \\
\text { el }\end{array}$ & $\begin{array}{l}\text { Jord } \\
\text { an }\end{array}$ & $\begin{array}{l}\text { Kuw } \\
\text { ait }\end{array}$ & $\begin{array}{l}\text { Leban } \\
\text { on }\end{array}$ & $\begin{array}{l}\text { Lib } \\
\text { ya }\end{array}$ & $\begin{array}{l}\text { Maurit } \\
\text { ania }\end{array}$ & $\begin{array}{l}\text { Moro } \\
\text { cco }\end{array}$ & $\begin{array}{l}\text { Om } \\
\text { an }\end{array}$ & $\begin{array}{l}\text { Qat } \\
\text { ar }\end{array}$ & $\begin{array}{l}\text { Saudi } \\
\text { Arabia }\end{array}$ & $\begin{array}{l}\text { Sud } \\
\text { an }\end{array}$ & $\begin{array}{l}\text { Syri } \\
\text { a }\end{array}$ & $\begin{array}{l}\text { Tuni } \\
\text { sia }\end{array}$ & UAE & $\begin{array}{l}\text { Yem } \\
\text { en }\end{array}$ & $\begin{array}{l}\text { Tota } \\
\text { I }\end{array}$ \\
\hline 19 & 1.01 & & 0.5 & 1.10 & & 0.4 & 0.18 & 0.21 & & 0.7 & & & & 0.0 & & 0.02 & 0.6 & 0.14 & 0.23 & 0.07 & \\
\hline 96 & 5 & 0.015 & 89 & 4 & 0.22 & 47 & 0 & 1 & 0.21 & 2 & 0 & 0.134 & 0.02 & 14 & 2.138 & 8 & 19 & 5 & 5 & 4 & 8.12 \\
\hline 19 & 1.08 & & 0.7 & 0.95 & & 0.6 & 0.13 & 0.29 & & 0.7 & & & & 0.0 & & 0.03 & 0.7 & & & 0.08 & 7.80 \\
\hline 97 & 5 & 0.032 & 04 & 3 & 0 & 25 & 7 & 7 & 0.235 & 2 & 0 & 0.105 & 0.02 & 24 & 1.553 & 5 & 25 & 0.18 & 0.29 & 7 & 6 \\
\hline 19 & & & 0.8 & 0.62 & & 0.7 & 0.14 & & & 0.4 & & & & 0.0 & & 0.04 & 0.6 & 0.41 & 0.27 & 0.06 & 7.17 \\
\hline 98 & 1.13 & 0.047 & 67 & 8 & 0 & 62 & 9 & 0.17 & 0.185 & 38 & 0.000 & 0.146 & 0.22 & 74 & 1.144 & 6 & 17 & 4 & 2 & 2 & 5 \\
\hline 19 & & & 0.5 & 0.79 & & 0.8 & 0.10 & 0.16 & & 0.6 & & & 0.02 & 0.0 & & 0.04 & 0.5 & 0.30 & 0.41 & 0.08 & 6.97 \\
\hline 99 & 1.09 & 0.023 & 76 & 4 & 0 & 84 & 5 & 7 & 0.173 & 42 & 0.002 & 0.135 & 9 & 22 & 0.946 & 1 & 39 & 5 & 9 & 9 & 9 \\
\hline 20 & 1.57 & & 0.5 & 1.05 & & 1.1 & 0.12 & 0.23 & & 0.8 & & & 0.02 & 0.0 & & 0.04 & 0.7 & 0.22 & 0.35 & & 8.71 \\
\hline 00 & 6 & 0.058 & 16 & 2 & 0 & 56 & 7 & 5 & 0.151 & 82 & 0.003 & 0.143 & 5 & 21 & 1.348 & 2 & 3 & 7 & 6 & 0.07 & 7 \\
\hline 20 & 1.48 & & 0.5 & & & 1.3 & 0.13 & 0.22 & & 0.9 & & & 0.03 & 0.0 & & 0.05 & 0.7 & 0.21 & 0.44 & 0.10 & 9.02 \\
\hline 01 & 6 & 0.026 & 13 & 1.2 & 0 & 35 & 2 & 8 & 0.21 & 15 & 0.004 & 0.136 & 1 & 14 & 1.23 & 6 & 45 & 4 & 5 & 0 & 2 \\
\hline 20 & 1.07 & & 0.4 & 1.25 & & 1.4 & 0.13 & 0.16 & & 0.2 & & & 0.03 & 0.0 & & 0.07 & 0.5 & 0.19 & 0.55 & & 7.42 \\
\hline 02 & 2 & 0.036 & 45 & 5 & 0 & 06 & 5 & 6 & 0.229 & 07 & 0.012 & 0.207 & 2 & 26 & 0.676 & 2 & 82 & 3 & 8 & 0.12 & 7 \\
\hline 20 & 1.07 & & 0.5 & 2.39 & 0.87 & 1.5 & 0.16 & 0.18 & & 0.2 & & & 0.02 & 0.0 & & 0.07 & 0.6 & 0.31 & 0.81 & 0.15 & 10.6 \\
\hline 03 & 4 & 0.044 & 35 & 5 & 1 & 43 & 7 & 2 & 0.22 & 88 & 0.006 & 0.258 & 4 & 24 & 0.95 & 1 & 72 & 8 & 7 & 6 & 12 \\
\hline 20 & 1.43 & & 0.7 & 2.77 & 1.96 & 2.0 & 0.24 & 0.29 & & 0.4 & & & 0.03 & 0.0 & & 0.10 & 0.6 & 0.35 & 1.32 & 0.20 & 14.6 \\
\hline 04 & 2 & 0.073 & 28 & 5 & 6 & 29 & 4 & 2 & 0.382 & 2 & 0.010 & 0.436 & 1 & 53 & 1.123 & 1 & 42 & 7 & 7 & 5 & 24 \\
\hline 20 & 1.66 & & 0.9 & 4.38 & 2.81 & 2.2 & 0.31 & 0.25 & & 0.5 & & & 0.04 & 0.1 & & 0.15 & 0.6 & 0.41 & 1.88 & 0.20 & 19.2 \\
\hline 05 & 9 & 0.061 & 55 & 3 & 7 & 72 & 7 & 2 & 0.341 & 79 & 0.011 & 0.514 & 4 & 33 & 1.549 & 3 & 94 & 2 & 1 & 0 & 35 \\
\hline 20 & 1.73 & & 1.1 & 6.69 & 2.71 & 2.3 & 0.33 & 0.27 & & 0.7 & & & 0.07 & 0.4 & & 0.22 & 0.6 & 0.47 & 2.33 & 0.19 & 23.0 \\
\hline 06 & 9 & 0.080 & 02 & 4 & 1 & 11 & 1 & 5 & 0.367 & 31 & 0.009 & 0.725 & 3 & 09 & 1.606 & 5 & 09 & 5 & 8 & 8 & 09 \\
\hline 20 & 2.17 & & 1.5 & 8.05 & 2.96 & 2.7 & 0.40 & 0.31 & & 0.2 & & & 0.11 & 0.4 & & 0.18 & 1.0 & & 3.71 & 0.27 & 28.9 \\
\hline 07 & 6 & 0.196 & 56 & 7 & 4 & 4 & 1 & 2 & 0.509 & 6 & 0.019 & 0.920 & 6 & 8 & 2.223 & 8 & 57 & 0.76 & 1 & 5 & 18 \\
\hline 20 & 3.20 & & 2.3 & 10.2 & & 3.3 & 0.48 & 0.57 & & 1.4 & & & 0.22 & 1.2 & & 0.24 & 1.4 & 1.14 & 8.66 & 0.35 & 44.6 \\
\hline 08 & 1 & 0.402 & 13 & 3 & 4.05 & 83 & 6 & 4 & 0.844 & 11 & 0.023 & 1.318 & 6 & 33 & 3.111 & 3 & 39 & 4 & 7 & 4 & 52 \\
\hline 20 & 2.54 & & 3.2 & 5.43 & 5.24 & 2.5 & 0.47 & 0.39 & & 2.1 & & & 0.12 & 0.3 & & 0.25 & 1.6 & 0.88 & 3.56 & & 33.6 \\
\hline 09 & 6 & 0.138 & 41 & 1 & 4 & 97 & 6 & 6 & 0.798 & 53 & 0.024 & 0.833 & 2 & 75 & 2.544 & 5 & 43 & 1 & 4 & 0.34 & 38 \\
\hline
\end{tabular}




\begin{tabular}{|c|c|c|c|c|c|c|c|c|c|c|c|c|c|c|c|c|c|c|c|c|c|}
\hline 20 & 2.57 & & 3.1 & 10.6 & & 3.4 & 0.61 & & & 2.3 & & & 0.16 & 0.3 & & 0.23 & 2.2 & 0.99 & 4.03 & 0.33 & 43.7 \\
\hline 10 & 3 & 0.244 & 77 & 89 & 6.19 & 4 & 4 & 0.61 & 0.847 & 58 & 0.039 & 1.021 & 9 & 4 & 3.598 & 3 & 97 & 4 & 1 & 1 & 94 \\
\hline 20 & 2.62 & & 4.1 & 16.0 & 8.39 & 4.4 & 0.50 & 0.56 & & 0.8 & & & 0.27 & 0.6 & & 0.25 & 1.9 & 1.05 & 5.35 & 0.27 & 54.9 \\
\hline 11 & 1 & 0.272 & 42 & 51 & 7 & 49 & 7 & 8 & 1.001 & 87 & 0.091 & 1.341 & 1 & 69 & 4.765 & 3 & 47 & 2 & 6 & 3 & 12 \\
\hline 20 & 2.73 & & 5.0 & 21.8 & 10.9 & 4.0 & 0.86 & 0.56 & & 2.5 & & & 0.32 & 0.7 & & 0.29 & 0.5 & 0.99 & 11.7 & 0.48 & 71.7 \\
\hline 12 & 8 & 0.367 & 21 & 86 & 72 & 4 & 7 & 9 & 0.176 & 56 & 0.115 & 1.444 & 1 & 24 & 5.848 & 1 & 65 & 2 & 71 & 6 & 51 \\
\hline 20 & 2.71 & & 4.8 & 14.5 & 12.0 & 5.0 & 0.81 & 0.62 & & 3.0 & & & 0.52 & 0.6 & & 0.29 & 1.1 & 1.18 & 10.3 & 0.60 & 66.9 \\
\hline 13 & 7 & 0.372 & 29 & 76 & 95 & 68 & 5 & 6 & 1.006 & 57 & 0.107 & 1.765 & 4 & 18 & 5.206 & 5 & 09 & 1 & 5 & 5 & 22 \\
\hline 20 & & & 4.7 & 13.7 & 11.1 & 5.8 & 1.03 & 0.56 & & 2.3 & & & 0.59 & 0.7 & & & 1.9 & 1.11 & 7.90 & 0.64 & 64.5 \\
\hline 14 & 3 & 0.498 & 32 & 2 & 56 & 32 & 3 & 9 & 0.923 & 04 & 0.108 & 2.046 & 2 & 39 & 5.39 & 0.32 & 17 & 2 & 9 & 9 & 48 \\
\hline 20 & 2.56 & & 4.3 & & 8.84 & 4.3 & 0.96 & 0.62 & & 1.6 & & & 0.38 & 0.7 & & 0.44 & 1.5 & 0.96 & & 0.40 & 53.2 \\
\hline 15 & 6 & 0.33 & 41 & 9.76 & 7 & 71 & 3 & 4 & 0.790 & 16 & 0.110 & 2.048 & 5 & 84 & 5.59 & 9 & 74 & 3 & 6.69 & 7 & 05 \\
\hline 20 & & & 4.1 & 9.66 & 8.47 & 4.3 & 0.81 & 0.54 & & 1.0 & & & 0.29 & 0.7 & & & 1.3 & 1.12 & 9.10 & 0.53 & 53.5 \\
\hline 16 & 2.2 & 0.321 & 76 & 6 & 3 & 41 & 3 & 2 & 0.817 & 67 & 0.088 & 2.387 & 3 & 1 & 5.007 & 0.51 & 87 & 5 & 8 & 6 & 68 \\
\hline 20 & & & 4.3 & 10.7 & 10.5 & 4.9 & 0.79 & 0.60 & & 1.1 & & & 0.31 & 0.9 & & 0.48 & 1.4 & 1.11 & 14.7 & 0.57 & 64.1 \\
\hline 17 & 2.48 & 0.414 & 58 & 51 & 82 & 13 & 5 & 9 & 1.021 & 29 & 0.0132 & 2.582 & 7 & 13 & 4.845 & 1 & 34 & 9 & 31 & 2 & 77 \\
\hline
\end{tabular}

Source: Turkstat, 2018. 
Overall, the past decade and a half or so has seen Turkey's economic interaction with the rest of the MENA expand rapidly and deepen. Total trade volume has increased so rapidly that economic integration has deepened drastically between Turkey and the region as a whole, even though Turkey has maintained an overall trade surplus. The make-up of Turkey's trade with the region, however, has not led to Turkey's economy becoming the central market in the region (the GCC states collectively still hold the most economically influential position) yet it has developed significant trade with all states considered here - something which other MENA states cannot claim to have managed to achieve.

Figure 2. Turkey's Total Trade with the MENA, 1996-2017 (US\$ billions)

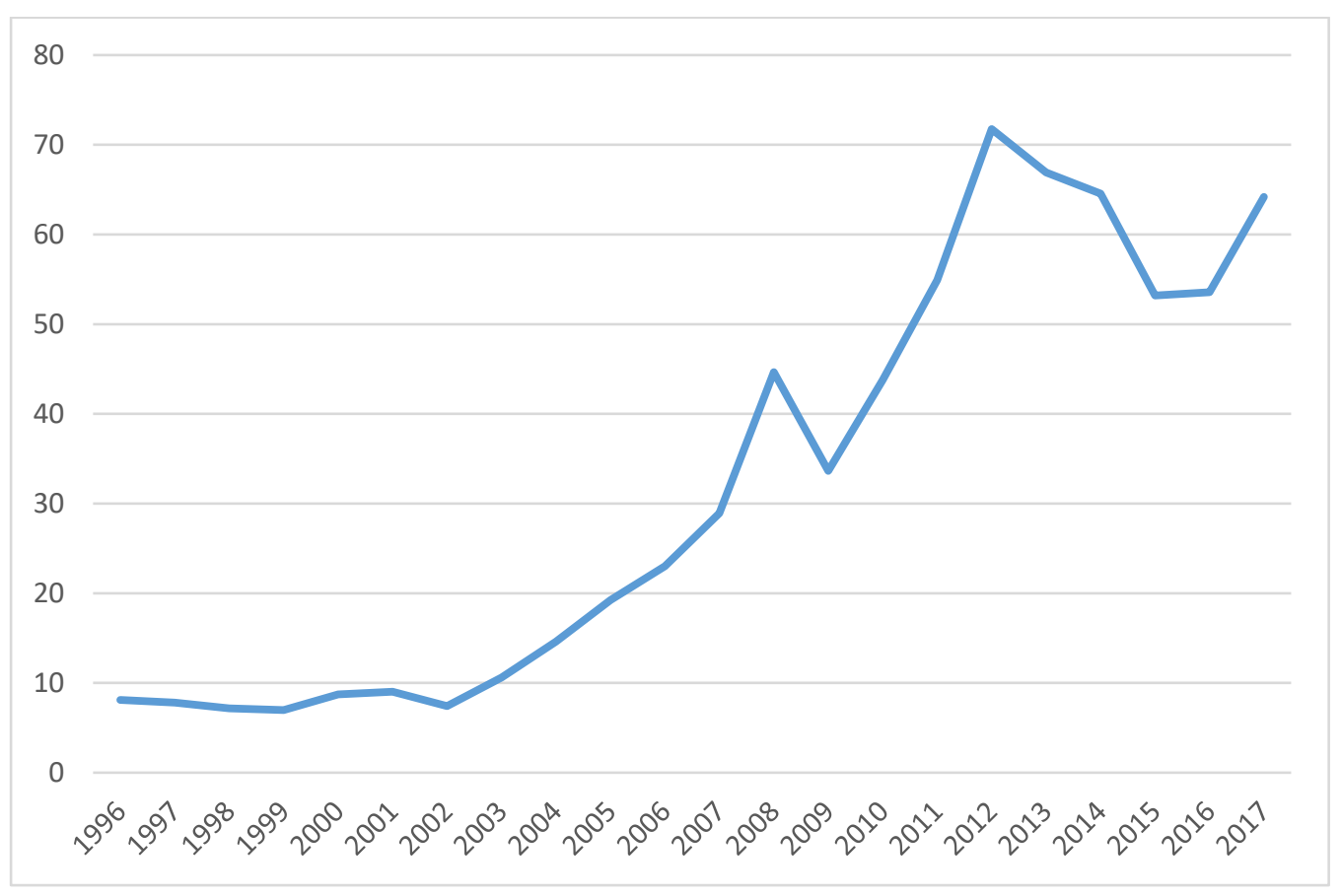

Source: TurkStat (www.turkstat.gov.tr), 2018.

\section{Foreign Direct Investment}

The second pillar of economic integration is FDI. While trade in goods and services demonstrates economic integration in the form of production, exchange and consumption (important features that speak to the health and stability of national economies), perhaps more important in terms of signalling deep economic integration between states is FDI. Producers of goods and services will always seek to increase sales and profits and will do so by exploiting opportunities in any market where it is profitable to do so. Turkey's trade with the MENA as discussed above, therefore, does not demonstrate significant trust and interest as much as it does profiteering. Investing capital (whether liquid or fixed) in foreign markets, on the other hand, does signal trust and interest - which are central to reinforcing economic integration and interdependence (see: Bearce 2003; Bearce and Omori 2005) - and can tie markets together.

Capital flows in the form of FDI between Turkey and the MENA in the past two decades or so have been important but somewhat limited (totalling just over \$14 billion). Interestingly, change in FDI flows does not mirror the overall trends in Turkey-MENA trade in goods and services since the 
turn of the millennium. Prior to 2005, total FDI levels were insignificant and certainly far below what one might expect, although this began to change with overall growth in FDI levels. However, after 2005 , a period of notable annual increases followed by equally notable annual declines in bilateral FDI emerged (see Figure 3). The growth seen may have been linked to the rise of the AKP in 2002 and subsequent macro-economic policy changes, although further research is needed to verify this hypothesis. Total FDI stood at $\$ 1.7$ billion in 2005 , increased slightly the following year to just under $\$ 2$ billion, but then declined rapidly in 2007 to $\$ 713$ million. Even as the global financial crisis began to bite in 2008 FDI rapidly increased to $\$ 2.6$ billion but then dropped to \$397 million in 2009 (the second lowest level since 2005). The impact of the global downturn lingered in the MENA as whole, as it did elsewhere around the world, and negatively impacted the Turkish economy more than most other large economies in the region. This may help explain the poor performance of Turkey-MENA FDI between 2009-2011. The Arab Spring did not hinder FDI in 2012 (\$1.4 billion) and 2013 (\$1.6 billion) but the intensification of the regional instability best demonstrated by the Syrian civil war, as well as the increasing centralisation of power in Ankara suppressed FDI since 2014 with 2017 seeing only $\$ 448$ million in bilateral FDI between Turkey and MENA states.

Even though total FDI levels have not been high or even constant over the past decade or more, importantly, Turkey has maintained an overall FDI surplus with the region in each year as FDI inflows to Turkey outstripped net outflows. Furthermore, these surpluses were significant in 2005 (\$1.7 billion), 2006 (\$1.9 billion), 2008 (\$1.9 billion), 2012 (\$1.1 billion) and 2013 (\$1.6 billion) representing a source of external income that has helped to slightly offset Turkey's unfavourable terms of trade with its main economic partners in Europe, North America and Asia. Turkey's smallest surplus came in 2017 with a mostly insignificant $\$ 10$ million. This overall surplus demonstrates the relative attractiveness of the Turkish market for MENA investors and the relative lack of trust and interest that Turkish investors have in MENA markets. It is also an indicator of the inward orientation of Turkish investors who have had success at home during a period of solid economic growth since 2002. Yet, while trade levels recovered and continued the high annual growth rates seen before the 2008-2009 global financial crisis, the stagnation of FDI levels suggests there are structural limitations to Turkey's economic reintegration with the region. This could signal that both state and non-state actors in the MENA have struggled to raise capital for investment abroad, or that Turkey's economy offers limited incentives for foreign capital (or both). Of course, the aftermath of the 2016 coup attempt in Turkey has led to a stiffening of AKP policies, including greater scrutiny of foreign capital ventures and this could well discourage FDI inflows from the MENA and elsewhere.

Figure 3. Turkey's FDI Flows with the MENA 2005-2017 (US\$ millions) 


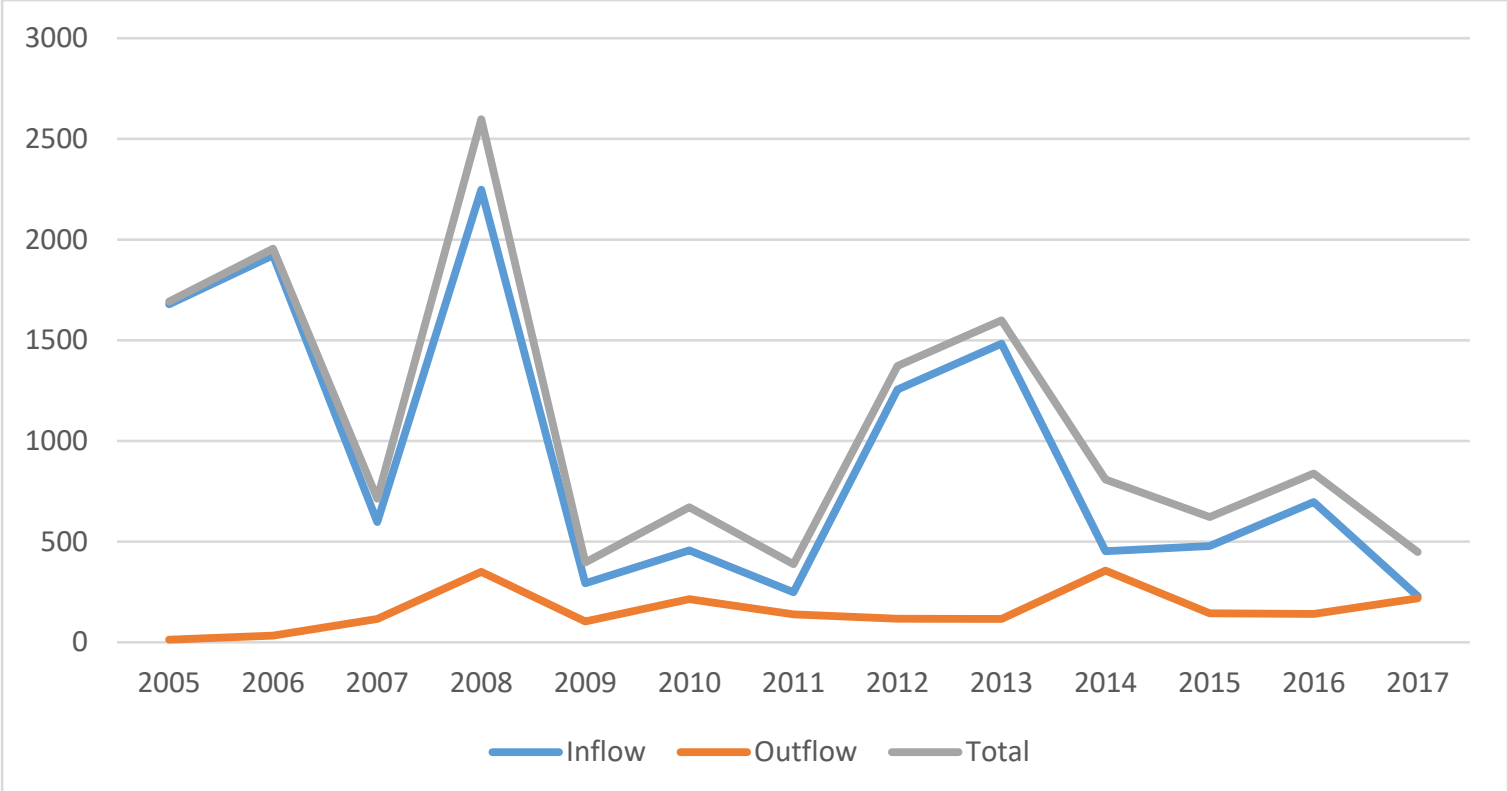

Source: Central Bank of the Republic of Turkey (CBRT): Statistical Data (EVDS), 2018.

Undoubtedly, Turkey-MENA FDI flows since the turn of the millennium have favoured the former and the long-term trend, despite the limitations witnessed in the past few years and the inconsistent annual FDI levels, demonstrates this. Turkey has had FDI surpluses with 10 states with its largest unsurprisingly being with hydrocarbon rich GCC states with large amounts of petro-dollars to invest. Since 2005, Turkey's largest surplus is with the UAE (approximately $\$ 3.8$ billion: $\$ 4.2$ billion inflow and $\$ 381$ million outflow), its second is with Saudi Arabia (just over $\$ 1.9$ billion: $\$ 2$ billion inflow and only $\$ 68$ million outflow), its third is with Kuwait (approximately $\$ 1.592$ billion: $\$ 1.7$ billion inflow and only $\$ 32$ million outflow), and its fourth is with Qatar (\$1.589 billion: \$1.621 billion inflow and only \$32 million outflow). Meanwhile, Turkey's largest FDI deficit is with Iraq (-\$422 million) which is unsurprising given the lack of Iraqi investor power and the investment opportunities for reconstruction in Iraq since 2003. Turkey also has significant deficits with Egypt (-\$225 million) and Tunisia (\$-223 million) which have received modest Turkish FDI (\$227 million and \$223 million, respectively) but have sent virtually no FDI to Turkey over this period (Egyptian FDI totalled only \$2 million and Tunisia \$0). Furthermore, the geographical spread of FDI inflows is relatively broad with states across the region investing in Turkey and receiving investments from Turkish sources, however, FDI flows are largely limited to the more prosperous (hydrocarbon rich and/or more industrialised) states and immediate neighbours. Turkey has been perhaps the most attractive MENA market for FDI from across the region over the past twenty years or so, which has helped to slightly re-position it as a key market in the broader regional economy. However, political uncertainty within Turkey and other MENA states, as well as structural economic vulnerabilities inherent within the regional economic system (chief among them: reliance on the export of hydrocarbons and the rentierism that is prevalent in most states (whether resource rich or poor)) may restrict further economic integration. Turkey's integration into regional capital flows appears to have reached its ceiling.

Table 4. Turkey's Total FDI Flows with MENA States, 1990-2016 (US\$ millions)

\begin{tabular}{|l|l|l|l|l|}
\hline & FDI Inflows & FDI Outflows & FDI Total & FDI Balance \\
\hline
\end{tabular}




\begin{tabular}{|l|r|r|r|r|} 
Algeria & 0 & 105 & 105 & -105 \\
\hline Bahrain & 484 & 183 & 667 & 301 \\
\hline Egypt & 2 & 227 & 229 & -225 \\
\hline Iran & 103 & 155 & 258 & -52 \\
\hline Iraq & 11 & 433 & 444 & -422 \\
\hline Israel & 395 & 12 & 407 & 383 \\
\hline Jordan & 216 & 7 & 223 & 209 \\
\hline Kuwait & 1648 & 56 & 1704 & 1592 \\
\hline Lebanon & 1280 & 28 & 1308 & 1252 \\
\hline Libya & 98 & 36 & 134 & 62 \\
\hline Mauritania & 0 & 0 & 0 & 0 \\
\hline Morocco & 0 & 87 & 87 & -87 \\
\hline Oman & 0 & 0 & 0 & 0 \\
\hline Qatar & 1621 & 32 & 1653 & 1589 \\
\hline Saudi Arabia & 1964 & 68 & 2032 & 1896 \\
\hline Sudan & 0 & 12 & 12 & -12 \\
\hline Syria & 11 & 17 & 28 & -6 \\
\hline Tunisia & 0 & 223 & 223 & -223 \\
\hline UAE & 4206 & 381 & 4587 & 3825 \\
\hline Yemen & 0 & 0 & 0 & 0 \\
\hline SOure: Centra & 0 & 0 & & 0 \\
\hline
\end{tabular}

Source: Central Bank of the Republic of Turkey (CBRT): Statistical Data (EVDS), 2018.

\section{Market Integration and Turkish Corporations}

Multi-national corporations (MNCs) play important roles in promoting and deepening economic integration between markets. They not only take part in processes of production, exchange and consumption, but also increase the opportunity costs of defection from cooperative relations at the same time as they increase the rewards of continued engagement for both state and non-state actors. As discussed above, businesspersons engage in international projects, play significant roles in developing and maintaining inter-personal relationships and can help connect political decisionmakers together through both formal and informal channels as part of their transboundary activities. Trust can be built in the private sector perhaps more easily than in the governmental sector, and on a regular basis (perhaps even we could say daily) corporate actors engage with each other. Furthermore, corporations based in one state but operating in others reinforce shared interests that are best-served by cooperative and stable political relationships. Turkish corporations have been among the most active and successful of any MNCs in the MENA and a large number operate in numerous sectors across the region. Turkey's 'active political role [in the MENA has] encouraged Turkish private enterprise to invest in construction, oil, natural gas and telecommunication systems' (Ehteshami and Elik 2011, 656-657) in a large number of states in the region. The roles MNCs play are not easily captured by macro-economic measure such as trade and FDI, so we will now turn to some specific examples.

Turkish corporations working in the construction sector have been highly successful since the early 2000s. Much of this work has been commissioned by national governments, has involved largescale infrastructure projects, and has been related to important and politically sensitive issues such as energy security, resource security, social welfare, and defence. In Algeria, for example, KAYI 
Construction and its subsidiary Bilyap Construction, ENKA Insaat, Rönesans Holding (Rönesans 2018), and Yapi Merkezi have been very active. KAYI Construction and Bilyap Construction have completed a large number of projects including residential complexes, hotels, official administrative buildings, container terminals, retail centres, power plants, military infrastructure and educational institutions (Kayi 2018). ENKA Insaat (ENKA 2018) has been involved in the building of dams and water treatment infrastructure, while Yapi Merzeki (Yapi 2018) constructed the Bir Touta-Zeralda Railway and Sidi Bel Abbes tramway. In Iraq, KAYI Construction has been involved in building and restoring power generation infrastructure, hydrocarbons processing and transport facilities, and healthcare centres among other projects. ENKA Insaat has also been involved in building power plants and hydrocarbon pumping infrastructure in Iraq as well as marine works (mostly in Basra). As a measure of their competitiveness, many Turkish corporations not only operate in neighbouring countries but across the region. For example, TAV Construction (TAV 2018) has been involved in numerous airport and aviation infrastructure projects in Bahrain, Egypt, Libya, Oman, Qatar, Saudi Arabia, Tunisia and the UAE since it was founded in 1997.

\section{Conclusions}

Regardless of the internal processes shaping its domestic politics, Turkey's economic integration with the MENA looks set to deepen, largely due to the increasing levels of trade in goods and services, and the agency of Turkey's private sector actors and the links they have established with the broader MENA market. Coupled with the structural changes most clearly manifest in commercial institutions, Turkey has become a more central component of the MENA system than at any time in the post-World War One era. The MENA has become an important market for Turkish exports and imports, and a source of FDI, which have combined to further strengthen growth in the Turkish economy. The overall trade and FDI surpluses that Turkey has experienced vis-à-vis the MENA since the early 2000s have helped to offset some of the less advantageous economic relationships it has experienced with European, North American and Asian states. Growth in bilateral trade with MENA states, in particular, has been very strong and although there have been some negative effects of the instability felt in some post-Arab Spring states and within Turkey itself, growth looks set to continue in the coming decade. Turkey is a trading state and the neoliberal economic reforms begun in the 1980s have become entrenched (even though political liberalisation has taken steps backwards) leading to Turkey's economic growth relying on Ankara diversifying its foreign markets and developing economic relations with MENA states as well as other countries around the world.

Economic integration with the MENA and its potential spill-over effects into political, security and socio-cultural relationships may face some limitations, however. The rather mixed record of Turkey-MENA FDI and the apparent limitations on the expansion of capital flows across the region suggest that investors in Turkey and other MENA states do not have absolute trust and interest in each other's markets. Political instability, the lack of profitable opportunities to invest and political restrictions will continue to hinder this important aspect of economic integration in the coming years. Without expanding economic links through FDI, Turkey's role in the MENA market can continue to grow, but this role will be limited to processes of production, exchange and consumption. These processes, ultimately, will integrate Turkey further into the region but will not likely allow Turkey to become the centre of the MENA economy. Furthermore, increased trade will most likely go some way to promoting political cooperation between Turkey and other MENA states over time but is unlikely to lead to the type of economic interdependence that promotes regional security. If Ankara aspires to greater regional leadership, or even hegemony, then it will have to facilitate FDI further and promote Turkish private sector actors as they engage more in the regional market. 


\section{Reference List}

Ageliki, Anagnostou and Panteladis Ioannis. 2016. "Eurasian Orientation and Global Trade Integration: The Case of Turkey." Eurasian Economic Review 6, no. 2 (Summer): 275-287.

Aydin, Aysegul. 2010. "The Deterrent Effects of Economic Integration." Journal of Peace Research 47, no. 5 (Summer): 523-533.

Aydin, Levent and Mustafa Acar. 2013. “Economic Implications of Turkey's Regional Integration with Its Neighbourhood." Bilig No. 66 (Summer): 42-58.

Barbieri, Katherine. 1996. "Economic Interdependence: A Path to Peace or a Source of Interstate Conflict?" Journal of Peace Research 33, no. 1 (Winter): 29-49.

Bearce, David H. 2003. "Grasping the Commercial Institutional Peace." International Studies Quarterly 47, no. 3 (Autumn): 347-370.

Bearce, David H. and Sawa Omori. 2005. "How Do Commercial Institutions Promote Peace?" Journal of Peace Research 42, no. 6 (Autumn): 659-678.

Cagaptay, Soner. 2009. "Is Turkey Leaving the West?" Foreign Affairs, October 26, 2009.

Central Bank of the Republic of Turkey (CBRT). 2018. "EVDS (Electronic Data Distribution System)." Accessed October 12, 2018. http://evds.tcmb.gov.tr/cbt.html

Donmez, Pinar and Eva Zemandl. 2019. "Crisis of Capitalism and (De-)Politicisation of Monetary Policymaking: Reflections From Hungary and Turkey." New Political Economy 24, no. 1 (Spring): $125-143$

Ehteshami, Anoushiravan and Suleyman Elik. 2011. "Turkey's Growing Relations with Iran and the Arab Middle East." Turkish Studies 12, no. 4 (Winter): 643-662.

Ekmekci, Faruk and Abdulkadir Yildirim. 2013. "The Political Economy of Turkey's Eastern Turn: An Empirical Analysis of Erdogan's State Visits (2003-2010)." Romanian Journal of Political Science Papers 13, no. 1 (Summer): 52-75.

El-Anis, Imad. 2018. "Economic Integration and Security in the Middle East and North Africa: What Prospects for a 'Liberal' Peace?" Journal of Developing Societies 34, no. 3 (Autumn): 233-263.

ENKA. 2018. "Our Projects." Accessed October 13, 2018. https://www.enka.com/our-projects/ Kardas, Saban. 2010. "Turkey: Redrawing the Middle East Map or Building Sandcastles?" Middle East Policy 17, no. 1 (Spring): 115-136.

Kayi. 2018. "Projects in Algeria." Accessed October 13, 2018. http://www.kayi.com.tr/projects/country/algeria

Kirişci, Kemal. 2009. "The Transformation of Turkish Foreign Policy: The Rise of the Trading State." New Perspectives on Turkey no. 40 (Spring): 29-56. 
Kirişci, Kemal, Nathalie Tocci and Joshua Walker. 2010. A Neighbourhood Rediscovered: Turkey's Transatlantic Value in the Middle East. Washington DC: German Marshall Fund for the United States.

Kirişci, Kemal. 2011. "Turkey's 'Demonstrative Effect' and the Transformation of the Middle East." Insight Turkey 13, no. 2 (Summer): 33-55.

Kutlay, Mustafa. 2011. “Economy as the 'Practical Hand' of 'New Turkish Foreign Policy': A Political Economy Explanation." Insight Turkey 13, no. 1 (December): 67-88.

Logan, David. 2009. "Turkey and its Middle Eastern Neighbours: Threat or Opportunity for the European Union?" Asian Affairs 15, no. 1 (Spring): 34-43.

Oneal, John R. and Bruce Russett. 1999. "The Kantian Peace: The Pacific Benefits of Democracy, Interdependence and International Organizations, 1885-1992." World Politics 52, no. 1 (Autumn): 1-37.

Öniş, Ziya and Suhnaz Yilmaz. 2009. "Between Europeanization and Euro-Asianism: Foreign policy Activism in Turkey During the AKP era." Turkish Studies 10, no. 1 (Spring): 7-24.

Öniş, Ziya and Fikret Senses (eds.). 2009. Turkey and the Global Economy: Neo-liberal Restructuring and Integration in the Post-crisis Era. Abingdon: Routledge.

Öniş, Ziya and Mustafa Kutlay. 2013. "Rising Powers in a Changing Global Order: The Political Economy of Turkey in the age of BRICS." Third World Quarterly 34, no. 8 (May): 1409-1426.

Polachek, Solomon W., John Robst and Yuan-Ching Chang. 1999. "Liberalism and Interdependence: Extending the Trade-Conflict Model." Journal of Peace Research 36, no. 4 (July): 405-422.

Pollack, Robert. 2005. "The Sick Man of Europe - Again?” Wall Street Journal, February 16, 2005.

Rönesans. 2018. "About Us." Accessed October 13, 2018. http://ronesans.com/en/about/about-us

Sorhun, Engin. 2013. "Arab Spring vs. Zero Problems Policy: Impact of the Arab Spring on the Trade Expansion of Turkey." International Journal of Research in Business and Social Science 2, no. 4 (October): 21- 36.

Suabsat, Turan. 2017. "Turkey at the Crossroads: The Political Economy of Turkey's Transformation." Markets, Globalization and Development Review 2, no. 2 (Spring): 1-32.

TAV. 2018. "About Us - Overview." Accessed October 13, 2018. http://tavconstruction.com/aboutus\#overview

Turkstat. 2018. "Foreign Trade Statistics." Acessed October 10, 2018 www.turkstat.gov.tr

World Bank. 2018. "Databank - World Development Indicators." Accessed October 10, 2018. http://databank.worldbank.org/data/source/world-development-indicators

Yapi. 2018. "Project Archive." Accessed October 9, 2018. http://www.ym.com.tr/en/projectarchieve/ 